
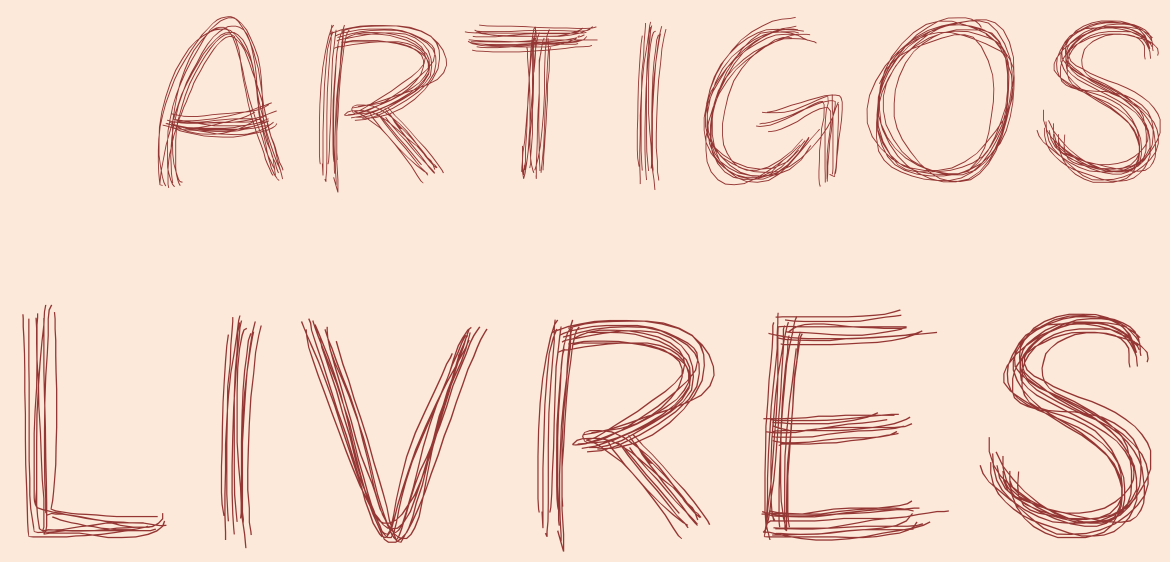


\title{
OS PRINCIPAIS CONCEITOS DA TEORIA DA HISTÓRIA DE JÖRN RÜSEN: UMA PROPOSTA DIDÁTICA DE SINTESE.
}

\author{
Wiliam Carlos Cipriani Barom \\ Doutor em Educação pelo Programa de Pós-Graduação em Educação da Universidade \\ Estadual de Ponta Grossa. Docente do Departamento de História da Universidade \\ Estadual de Ponta Grossa. \\ wiliam_barom@yahoo.com.br
}

resumo: Na última década, a Didática da História no Brasil vem passando por uma mudança ao se aproximar da área da ciência da história. De sua histórica relação com o ambiente escolar, vem avançando em direção ao estudo da cognição histórica, intra e extra escolar. Da filosofia e teoria da história, conceitos como cultura, consciência, narrativa e identidade parecem balizar este processo de ampliação do campo em direção ao estudo da aprendizagem histórica em sociedade. No Brasil, este processo vem sendo realizado substancialmente através das contribuições teóricas do filósofo e historiador alemão Jörn Rüsen. 0 presente artigo busca contribuir no entendimento deste processo ao sistematizar de modo didático os principais conceitos de sua teoria, na intenção de demonstrar suas inter-relações e dialogicidades.

palauras-chave: Consciência Histórica, Didática da História, Teoria da História. abstract: The Didactics of History in Brazil has been going through a shift when approaching the area of the science of history in the last decade. Of its historic relationship with the school environment is advancing toward the study of historical cognition, inside and outside of school. From within the philosophy and theory of history, concepts such as culture, consciousness, narrative and identity seem to mark out this process of expansion of the field toward the study of historical learning in society. In Brazil, this process is being carried out substantially through the theoretical contributions of the German philosopher and historian Jörn Rüsen. This article aims to contribute to the understanding of this process indicating the concepts of his theory, with the intention of demonstrating their interrelations and dialectic relations.

key-words: Historical Consciousness, Didactics of History, Theory of History. 
Brasil as contribuições teóricas do filósofo alemão Jörn Rüsen vêm subsidiando o processo de "mudança paradigmática" da Didática da história1. Do campo das teorias sobre as metodologias de ensino - da centralidade do ato de ensinar -, estaríamos presenciando o possível início de um processo de deslocamento do objeto da Dídática da história para o campo das reflexões sobre o aprendizado histórico em sociedade: as ideias históricas em relação com a cultura e como estas ideias participam na interpretação da realidade, nas ações no presente e nas perspectivas de futuro dos sujeitos, individualmente e em coletividade. Neste sentido, com o presente texto buscamos propor uma arquitetura didática dos principais conceitos do autor, recuperando apontamentos e interpretações de alguns dos principais comentadores nacionais da teoria. Um texto voltado especificamente para a formação profissional de futuros historiadores e pesquisadores iniciantes na área do ensino da história

O texto se dividirá em duas partes: a vida prática como substrato da teoria da história de Jörn Rüsen e consciência, narrativa e cultura: uma proposta de relação dialética. De modo sintético, buscaremos desenvolver a relação entre ciência e conhecimento comum no ofício do historiador (destacando o retorno e presença deste conhecimento na sociedade como forma de orientação); o conceito de consciência histórica e o seu contraponto consciência utópica, como eixo central ao redor do qual orbitam os demais conceitos da teoria rüseniana; a maneira como Rüsen entende a expressão desta consciência histórica via as narrativas históricas; formas variadas de recuperar o passado que implicam em distintas formações identitárias; e como estas ideias expressas nas narrativas podem estar em relação com os dados da cultura histórica, sendo formadas de maneiras difusas, nos espaços da vida social.

1 CERRI, L. F. Didática da História: uma leitura teórica sobre a História na prática. Revista de História Regional, v.15, p.264-278, 2010, p. 268. 


\section{a vida prática como substrato da teoria da história de jörn rüsen}

A teoria da história de Jörn Rüsen pode ser sintetizada na trilogia intitulada Grundzüge einer Historik (Fundamentos de uma teoria da história), publicada na Alemanha ao longo da década de 1980. A partir de 2001, estas obras foram inseridas no Brasil com a colaboração da Editora UNB, sob tradução dos professores Dr. Estevão Chaves de Rezende Martins e Asta-Rose Alcaide, da Universidade de Brasília. O primeiro volume da trilogia foi lançado com o título de Razão histórica: os fundamentos da ciência histórica', ganhando sequência seis anos depois, com os títulos Reconstrução do passado: os princípios da pesquisa histórica e História viva: formas e funções do conhecimento histórico ${ }^{4}$. Além destas obras, inúmeros artigos do autor também se encontram traduzidos e publicados no Brasil, além de outros em língua espanhola e inglesa que também circulam nacionalmente. Recentemente, o entendimento da teoria de Rüsen vem sendo complementado com quatro novas obras integrais do autor que foram lançadas pelas editoras Vozes, Editora UFPR e W.A. Editores 5 .

Uma teoria que se propõe a ser um exercício metateórico de análise da prática historiográfica e suas pretensões de validade, buscando ir além da reflexão sobre os métodos de pesquisa (heurística, crítica e hermenêutica), avançando no estudo da pretensão de racionalidade da ciência da história. Como afirma Rüsen, uma concepção de teoria tomada em seu sentido "clássico", que subentende a procura por "determinações racionais" - sendo racional todo pensamento histórico que se exprime sob a forma de uma argumentação - nos procedimentos relacionados à construção da história 6 .

Para o autor, os reais fundamentos do pensamento histórico estariam no cotidiano do historiador. Estes fundamentos, definidos como "princípios", seriam elementares, gerais e comuns a todos os seres humanos. Neste cotidiano, envolto a uma cultura, o historiador estaria em relação com o conhecimento histórico

\footnotetext{
2 RÜSEN, Jörn. Razão histórica: teoria da História: os fundamentos da ciência histórica. Brasília: UnB, 2001.

${ }^{3}$ RÜSEN, Jörn. Reconstrução do passado: teoria da História Il: os princípios da pesquisa histórica. Brasília: UnB, 2007a.
}

${ }^{4}$ RÜSEN, Jörn. História Viva: teoria da História III: formas e funções do conhecimento histórico. Brasília: UnB, 2007b.

5 RÜSEN, Jörn. Aprendizagem histórica: fundamentos e paradigmas. Curitiba: W.A. Editores, 2012; Cultura faz sentido: orientações entre o ontem e o amanhã. (Trad. Nélio Schneider). Petrópolis: Vozes, 2014; Humanismo e didática da história. (Org. Maria Auxiliadora Schmidt, Isabel Barca, Marcelo Fronza e Lucas Pydd Nechi). Curitiba: W.A. Editores, 2015; Teoria da história: uma teoria da história como ciência. (Trad. Estevão de Rezende Martins). Curitiba: Editora UFPR, 2015.

${ }^{6}$ Ibidem, 2001, p. 21. 
comum, que embora apresente uma diferença qualitativa com relação ao conhecimento histórico científico, estaria em complementariedade a este. Desta forma, caberia a teoria da história lançar uma reflexão sobre este cotidiano do historiador, de onde partem as angustias e anseios - substratos do pensamento histórico -, identificando e problematizando esta relação entre o trabalho metodológico e disciplinado e sua origem no pensamento comum, no cotidiano.

Assim, a teoria de Rüsen busca integrar as duas dimensões existentes no ofício do historiador: a da "ciência especializada" e da "vida prática". Como inseparáveís, e não estáticas, estas dimensões não se estancariam em ambientes díspares, compondo um único sistema dinâmico, no qual o conhecimento produzido retorna ao meío social onde foi produzido como orientação para a vida prática. Ou seja, a Teoria da História parte da reflexão do trabalho prático do historiador, baseia-se nele e possui para ele significado?

Emprestando a denominação matriz disciplinar de Thomas Kuhn, Rüsen sistematiza cinco princípios - fatores essenciais de todo pensamento histórico ${ }^{8}$ que estariam presentes no ofício do historiador, da origem de suas indagações, enraizadas na vida, ao retorno de seu trabalho historiográfico à sociedade. Seriam eles: Interesses, Ideias, Métodos, Formas e Funções. Esta organização que busca separar e dar visibilidade aos princípios permite à teoria da história, como estratégía metodológica, refletir sobre o modo específico pelo qual tanto o pensamento histórico, em geral, quanto à historiografía acadêmica, em particular, constituem sentido sobre a experiência do tempo. Um esquema que busca facilitar a compreensão, identificação e estabelecimento do sentido ("sinn") e potencializar reflexões sobre sua presença em cada um dos momentos que envolvem a prática historiográfica

Esta tentativa de abranger todos os elementos essenciais presentes na produção de histórias pelos historiadores profissionais acaba por representar uma solução aos impasses que, nos anos 1980, marcaram o debate sobre Históría e o conhecimento histórico. De acordo com Arthur Assis, a matriz disciplinar de Rüsen integrou pontos de vista discordantes, ao tentar

\footnotetext{
7 Podemos até dizer mais, a teoria da História parte das necessidades da vida cotidiana, de uma esfera não especializada do pensamento, da qual o historiador participa como pessoa. O reforço aqui é a ideia de que a ciência não é a superação do senso comum, mas a metodização de alguns dos seus componentes - "metodização significa sistematização e ampliação dos fundamentos que garantem a verdade" (Ibidem, 2007a, p. 13). Não se trata, pois, de uma divisão entre não-saber e saber, mas entre saberes distintos que podem se relacionar produtivamente.
}

8 Ibidem, 2007a, p. 14. 
[...] superar uma concepção estreita de objetividade - a qual, confiante nos métodos de pesquisa como meios infalíveis para descortinar as verdades escondidas nas fontes, sempre tende a recalcar o tema da representação histórica - quanto oferecer uma alternativa à visão radicalmente construtivista e narrativista de historiografía, que não esclarece satisfatoriamente a natureza da relação entre escrita e pesquisa históricas ${ }^{9}$.

Esta aproximação entre vida prática (práxis da vida) e a ciência da história é compreensível à luz de dois postulados existenciais: o de que os seres humanos vivem no horizonte do tempo e o de que o pensamento histórico está relacionado com a administração da experiência tempora ${ }^{10}$. Ou seja, por estarem imersos numa cultura, vivendo no mundo, os seres humanos precisam interpretar a realidade ao agir e esta interpretação se faz substancialmente a partir de dados da memória.

$\bigcirc$ primeiro princípio da matriz disciplinar, denominado interesses, representa este postulado enunciado. Seria o ponto de partida do pensamento histórico enquanto ciência e se refere às carências humanas de orientação ao agir. Por interesses, Rüsen entende o movimento inicial da consciência em direção ao passado para interpretar os desafios da realidade presente. Ao lado da denominação interesses, Rüsen associa a ideia de carências, ou seja, seriam as carências de orientação no presente que despertariam o interesse pelo passado, [... carências fundamentais de orientação da prática humana da vida no tempo, que reclamam o pensamento histórico; carências de orientação que se articulam na forma de interesse cognitivo pelo passado. ${ }^{11}$

Este passado reivindicado pelo presente se torna "história" na medida em que é uma interpretação, uma reflexão específica sobre o passado e que atríbui "sentido" a orientação da vida humana prática. A este respeito, sobre estes dados recuperados do passado é lançado um "modelo de interpretação" construído no presente e que dá organicidade a estes dados, atríbuindo-lhes significância. Este seria o segundo princípio da matriz disciplinar, definido como ideias. Nas palavras de Rüsen ${ }^{12}$, o passado passa a ser "experimentado", momento em que o conjunto de ideias do presente dão organicidade aos dados e informações do passado de modo a constituir uma orientação possível para o agir.

\footnotetext{
${ }^{9}$ ASSIS, A. A. A teoria da história de Jörn Rüsen. Uma introdução. Goiânia: Ed. UFG, 2010, p. 14.

10 Ibidem, p. 15.

${ }^{11}$ RÜSEN, Jörn, op.cit., 2001, p. 30.

12 Ibidem, p. 32.
} 
Como terceiro princípio da matriz disciplinar está o método. Refere-se a necessidade de submeter estas ideias, este constructo interpretativo das experiências do passado, e as experiências concretas (fontes/documentos) do passado, às regras da metodologia da pesquisa científica. $\bigcirc$ método como princípio elementar da ciência que qualifica a relação entre o homem, motivado por suas carências, e os dados recuperados do passado ${ }^{13}$.

Este novo conhecimento - leia-se regulado metodologicamente - que deriva da pesquisa precisa ser apresentado ao público de acordo com uma forma específica: a narrativa. Como quarto fundamento da matriz, denominado de forma de apresentação, Rüsen se refere a historiografia e a necessidade dela não perder 0 ganho qualitativo oriundo da regulação metódica ao atentar a questões estéticas e de oratória, "o recurso da argumentação discursiva não pode ser deixado de lado em benefício de imagens estáticas da história, infensas à análise crítica argumentativa do público" ${ }^{14}$.

Apontando a necessidade do conhecimento produzido retornar como orientação para a sociedade, Rüsen insere como último dos fundamentos da matriz disciplinar o princípio denominado função de orientação existencial Como resposta a uma pergunta, o conhecimento produzido deve retornar para a sociedade de modo a satisfazer às carências iniciais de orientação. Uma ciência em íntima ligação com a vida prática.

Estes cinco princípios estão organizados no esquema criado por Rüsen, disponível na obra Razão histórica:

13 Rüsen nos aponta que estes princípios da matriz não são necessariamente consequentes um do outro, cronologicamente. O método é capaz de influenciar também o modo pelo qual as perspectivas (ideias) são concebidas, e, desta forma, novas ideias podem ser formadas.

14 Ibidem, p.47. 
Figura 1: Matriz disciplinar.

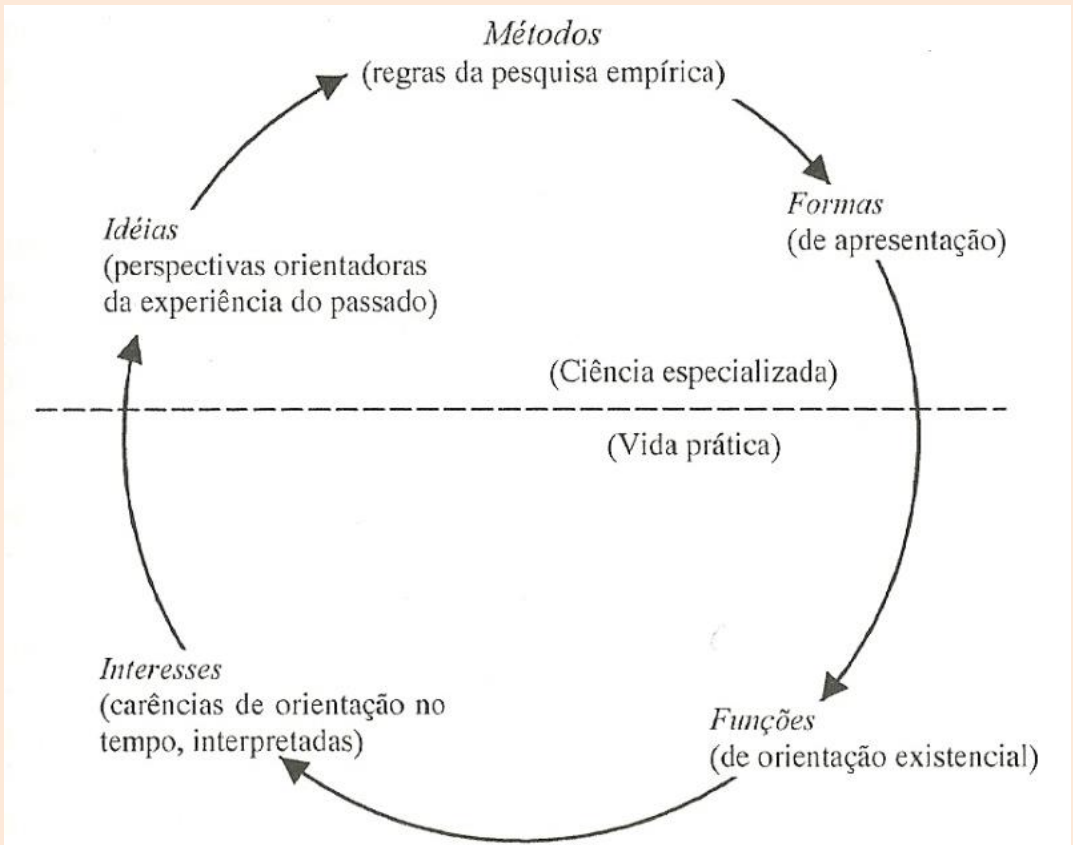

Esquema da matriz disciplinar da ciência da História ${ }^{15}$.

Este instrumento metodológico criado, uma organização ideal de cinco momentos que se relacionam ao ofício do historiador, possibilita à teoria da história refletir sobre a ligação existente entre a história, como produto historiográfico, e as carências de seu tempo. Atribuindo historicidade ao pensamento histórico, refuta modelos de história que se proponham como atemporais, como verdades absolutas ou reais representações dos fatos, apontando a necessidade da reconstrução constante da história, haja visto que as carências e ideias estão presas no tempo, portanto, sempre mudando.

No sentido de aprofundar esta compreensão do enraizamento da ciência na vida cotidiana, Rüsen articula sistematicamente um conjunto de conceitos da tradição histórico-filosófica alemã. Este conjunto - que vem sendo reivindicado pelas pesquisas educacionais e auxilia na expansão do campo da Didática da História - colabora na apreensão e entendimento do homem em sociedade, em sua relação com o tempo, imerso em uma cultura, donde partem os interesses e carências. Esta

15 Recentemente, o historiador Peter Seixas vem adaptando esta matriz na perspectiva da History Education. Para saber mais: http://public-history-weekly.oldenbourg-verlag.de/4-2016-6/ahistorymemory-matrix-for-historyeducation/?utm_campaign=twitter\&utm_medium=twitter\&utm_source=twitter\#comment-5788, acessado $18 / 03 / 2016$. 
relação entre pensamento histórico comum e cultura é o que buscamos recuperar no esquema criado abaixo.

Figura 2: Síntese esquemática dos conceitos presentes na teoria da história de Jörn Rüsen.

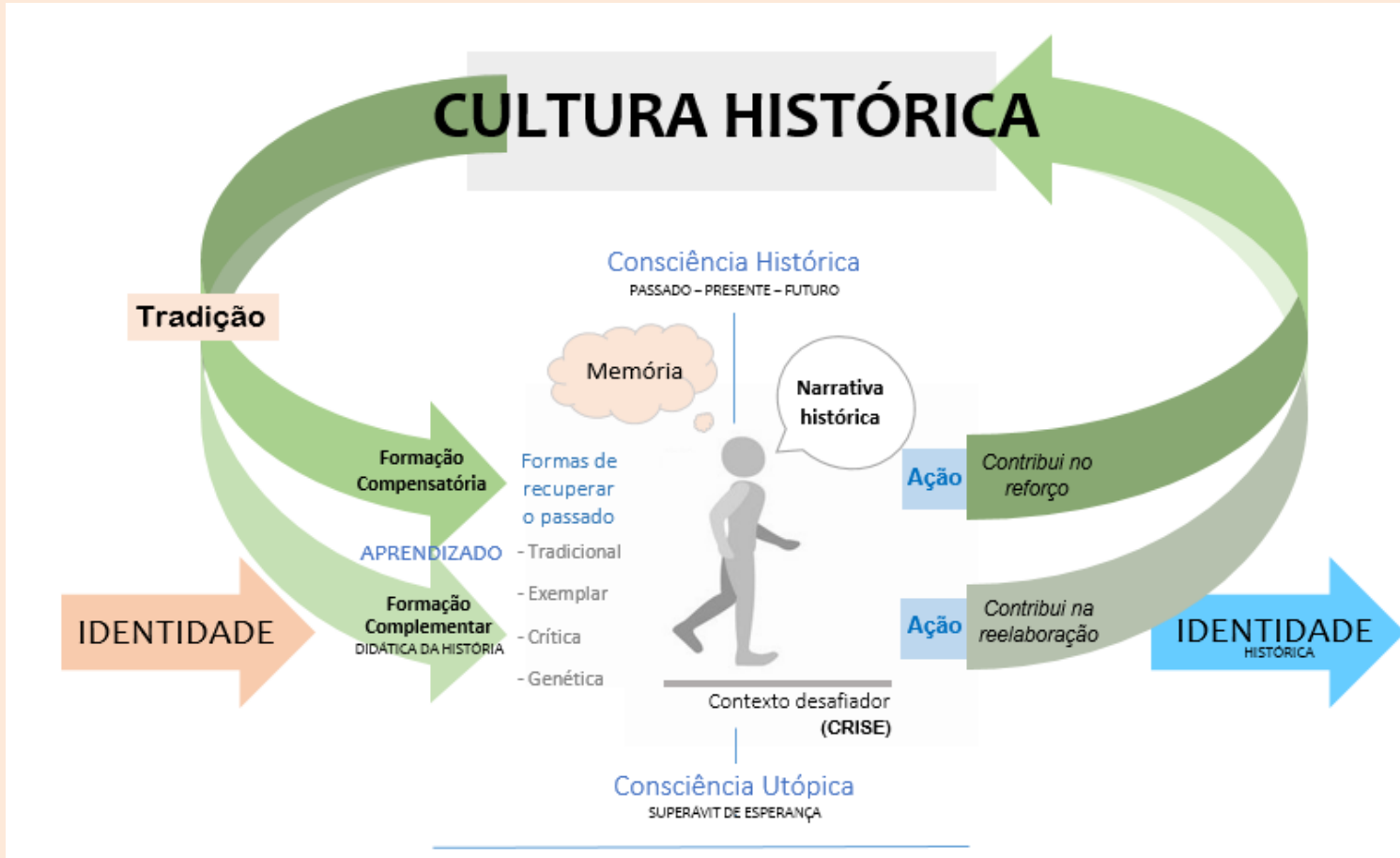

Fonte: o Autor $(2016)^{16}$. Relação dialética entre cultura histórica e consciência histórica.

Neste modelo, enquadram-se tanto o historiador no exercício da pesquisa histórica, como também a pessoa comum na orientação prática de sua vida cotidiana.

${ }^{16}$ A Imagem do homem andando está disponível em: https://www.colourbox.com/preview/8887548phases-of-step-movements-man-in-walking-sequence-for-game-animation-on-white.jpg. Acesso em: 08/02/2016. 


\title{
consciência, narrativa e cultura: uma proposta de relação dialética
}

\section{consciência histórica e consciência utópica}

O conceito de consciência histórica tem importância singular no interior da teoria rüseniana. E, ao seu redor é que os outros conceitos da teoria se articulam. Rüsen assim o define:

\begin{abstract}
Tenciono, pois, analisar os processos mentais genéricos e elementares da interpretação do mundo e de si mesmos pelos homens, nos quais se constitui o que se pode chamar de consciência histórica. (RÜSEN, 2001, p. 55). [...] quando se entende por consciência histórica a suma das operações mentais com as quais os homens interpretam sua experiência da evolução temporal de seu mundo e de si mesmos, de tal forma que possam orientar, intencionalmente, sua vida prática no tempo. ${ }^{17}$
\end{abstract}

Nestes dois trechos a ideia de consciência está atrelada ao que é comum e fundamental no ser humano diante da necessidade de interpretar as experiências do tempo. Estes "processos mentais" de interpretação se referem às articulações do pensamento na finalidade de criar um entendimento sobre o mundo e si próprio, de modo a poder agir na vida prática.

Consciência histórica não seria a mesma coisa que estado de consciência, que poderia ser analisada, medida ou mensurada. Convém entender este conceito a partir dos sinônimos utilizados pelo próprio Rüsen: "estruturas mentais", "operações do pensamento", "processos mentais de interpretação", "trabalho intelectual", "operações de constítuição elou rememoração de sentido". Assim, nos afastamos a priori de interpretações que atualmente acreditam poder "formar", "criar" ou "gerar" a consciência histórica nas pessoas unicamente a partir de intervenções pontuais ${ }^{18}$. Não se trata da dualidade saber x não saber, ou consciência x ignorância. Para Rüsen, a consciência histórica seria "universalmente humana" 19 .

17 RÜSEN, Jörn, op. cit., 2001, p. 55.

18 BAROM, W. C. C. Didática da História e consciência histórica: pesquisa na Pós-graduação brasileira (2001-2009). Dissertação (Mestrado em Educação) - Universidade Estadual de Ponta Grossa (UEPG). Ponta Grossa, 2012, p. 77.

${ }^{19}$ RÜSEN, Jörn, op. cit., 2001 , p. 78. 
Por ser uma operação abstrata, um trabalho do intelecto de recorrer a dados da memória para interpretar o presente e possibilitar ações no mundo, a consciência histórica não seria visualizada ou percebida imediatamente, o que dificulta um pouco a sua instrumentalização pelas pesquisas científicas. Ela está implícita nas ações das pessoas, é percebida à posteriorí, mesmo sendo condição necessária para a ação.

Para o professor Oldimar Cardoso, a dificuldade de precisão no entendimento de consciência histórica está relacionada às diferentes apropriações deste conceito ao longo da história, seja por sua assimilação por autores francófonos - conscience historique - ou gemanófonos - GeschichtsbewuBtsein. A expressão reuniria em si pelo menos quatro significados: consciência histórica como sinônimo de consciência da disciplina da história, uma representação sobre ela ou sobre a forma como ela organiza simbolicamente o mundo, apropriação de Nicole TutiauxGuillon e Marie-José Mousseau; como o entendimento da inserção social de um indivíduo ou de um grupo na História de sua sociedade, aproximando-se do conceito de Henri Moniot de mémoire, mémoire collective e identité, como consciência da temporalidade histórica, da capacidade humana de situar-se e orientar-se no tempo a partir da linguagem, utilização de Dagmar Klose e Bernard Lepetit; e a concepção adotada por Rüsen, como "fundamento de todo conhecimento histórico", "um modo elementar do pensamento humano" 20.

Para o historiador Luís Fernando Cerri ${ }^{21}$, este conceito deve ser entendido como um fenômeno, como uma das expressões da existência humana, não necessariamente mediado por uma preparação teórica, uma filosofia ou uma teoria da história. Desta forma, desconsiderando o entendimento de consciência histórica como consciência política, na perspectiva de Raymond Aron, Cerri também aponta a pluralidade de interpretações ao redor do conceito enumerando três apropriações: a de Hans-Georg Gadamer, que relaciona o termo a um estado de consciência com relação ao tempo possível graças à evolução da ciência da história, do conhecimento especializado e erudito da contemporaneidade, assim a consciência histórica como um "privilégio do homem moderno"; a concepção de Phillipe Ariès sobre "tomada da consciência da história" do homem europeu no século XX, no sentido de que o

${ }^{20}$ CARDOSO, O. Para uma definição de Didática da História. Revista Brasileira de História, v.28, p.153170, 2008, p. 160.

${ }^{21}$ CERRI, L. F. Ensino de história e nação na propaganda do “milagre econômico" - Brasil: 1969-1973. 2000, 304f. Tese (Doutorado em Educação) - Universidade Estadual de Campinas, Campinas, São Paulo, 304f. Orientadora: Ernesta Zamboni, p. 156; e CERRI, L. F. Os conceitos de consciência histórica e os desafios da Didática da História. Revista de História Regional, Ponta Grossa, PR, v.6, n.2, p.93-112, 2001, p. 96. 
indivíduo passa a aperceber-se da condição de determinado pela história, além de influenciador dela; e a noção de Agnes Heller, na qual

[...] a consciência histórica é inerente ao estar humano no mundo
(desde a percepção da historicidade de si mesmo, que se enraíza na
idéía de que alguém estava aqui e não está mais, e que eu estou
aqui mas não estarei mais um dia) e é composta de diversos
estágios, que vão desde o momento em que um dado grupo cria
normas de convivência, substituindo com elas os instintos - em
que o sistema mítico do grupo legitima-o e significa, para ele, a
origem do universo, e em que o grupo é identificado à humanidade
- até o momento em que num dado grupo, após se ter tomado
consciência de que a humanidade transcende-o, concebe-se o
mundo como histórico (no sentido de construção humana,
desconectada de quaisquer fatores metafísicos) relativizando a
própria cultura a partir de outras, no tempo e no espaço, até a
consciência de que a história não marcha índelevelmente para o
progresso, que a racionalidade e a ciência não dão conta da evolução
humana e de que o futuro é missão de cada um e de todos. Nesse
percurso, teríamos chegado à configuração contemporânea da
consciência histórica. Mobilizar a própria consciência histórica não
é uma opção, mas uma necessidade de atribuçãa de significado. ${ }^{22}$

professor Rafael Saddi, recuperando Karl-Ernst Jeismann, uma das influências de Rüsen e Klaus Bergmann no cenário alemão, reflete sobre o momento em que este conceito passou a ser objeto da Didática da História a partír de seu entendimento como "o total das diferentes ideias e atitudes diante do passado". Tratar-se-ia, portanto, da suma dos modos como os homens se relacionam com o que já aconteceu. Para Jeismann, esta relação com o passado se daria a partír de formas variadas num mesmo tempo e, por não ser um "produto natural", a consciência histórica das pessoas variaria também ao longo da história, do fluxo do tempo, influenciadas e "propagadas pela tradição, modificadas pela experiência histórica, aumentadas pela crítica ou agitação, corrigidas ou não pela pesquisa documental" ${ }^{23}$. Um entendimento sincrônico e diacrônico de consciência histórica como "autocompreensão do presente" a partir do passado.

\footnotetext{
22 Ibidem, p. 99.
}

23 SADDI, R. O parafuso da didática da história: o objeto de pesquisa e o campo de investigação de uma didática da história ampliada. Acta Scientiarum. Education, v.34, p.211-220, 2012, p. 214. 
Em certa medida, o historiador Estevão Chaves de Rezende Martins aproxima estes variados entendimentos citados em sua definição dimensional do conceito:

Essa consciência histórica inclui diversas dimensões: consciência do tempo, da realidade, da historicidade da existência do agente, da identidade pessoal e grupal, da moral, da política, da sociedade como "meio ambiente envolvente", da economia como "circunstância de atuação laboral". O entrelaçamento dessas dimensões forma uma trama única, mas seus diversos fios podem ser analiticamente distinguidos e, com isso, fortemente valorizados pela estruturação da consciência histórica por força da atuação própria do agente racional ${ }^{24}$.

Concordamos com esta definição mais ampla do termo, em certa medida ela está contida nos desdobramentos do pensamento de Rüsen. Mas por hora, é mais profícuo ao texto - instrumentalizando-nos - atentarmos especificamente a este conceito a partir da aproximação com a ideia de "estruturas mentais" elementares.

Neste sentido, a apropriação de Rüsen do conceito se aproxima mais do entendimento de Agnes Heller, onde para ambos consciência histórica não seria uma meta a ser alcançada, mas um fenômeno cotidiano e inerente à condição humana, não estando restrito a um período da história, a regiões do planeta, a classes sociais ou a indivíduos mais ou menos preparados para a reflexão histórica ou social geral25. A consciência histórica entendida como produto da vida prática concreta, resultado da humana e íntima conexão entre o pensamento e a vida ${ }^{26}$, sendo, portanto, universal, estendida a todos os seres humanos.

${ }^{24}$ MARTINS, E. R. História: consciência, pensamento, cultura, ensino. Educar em Revista, Curitiba, n. 42, p. 43-58, 2011, p. 57. Em outro texto do autor, Cultura, história, cultura histórica (2012), Estevão Chaves de Rezende Martins atribui este entendimento dimensional do conceito de consciência histórica à HansJürgen Pandel, que havia identificado sete possíveis formas de consciência histórica no meio cultural: "1) consciência do tempo (presente, passado, futuro e a percepção da densidade histórica empírica, concreta da existência do agente); 2) consciência da realidade (percepção da distinção entre o real e o fictício); 3) consciência da historicidade (a composição entre o permanente e o mutável); 4) consciência identitária (formação e enunciação de si, percepção de si e de outros como pertencentes a determinado grupo; 5) consciência política (percepção das estruturas de organização, interesses e prevalência na sociedade); 6) consciência econômico-social (conhecimento das desigualdades sociais e econômicas engendradas em determinado percurso histórico da sociedade); 7) consciência moral (reconstrução de valores e normas vigentes e tradicionais, sem cair em relativismo absoluto nem abdicar de sua própria autonomia judicante)". MARTINS, E. R. Cultura, história, cultura histórica. ArtCultura, n.25, v. 14, p. 63-82, juldez, 2012, p. 69.

${ }^{25}$ CERRI, L.F, op. cit., 2001, p. 99.

${ }^{26}$ RÜSEN, J. op. cit., 2001, p. 55. 
Como um filtro, a consciência histórica regularia as intenções de futuro e as ações no presente a partir dos conteúdos e experiências rememoradas do passado.

\begin{abstract}
A consciência histórica é o trabalho intelectual realizado pelo homem para tornar suas intenções de agir conformes com a experiência do tempo. Esse trabalho é efetuado na forma de interpretações das experiências do tempo. Estas são interpretadas em função do que se tenciona para além das condições e circunstancias dadas da vida. ${ }^{27}$
\end{abstract}

De acordo com o seu maior ou menor poder de criticidade, e ai Rüsen inclui a importância do conhecimento regulado metodicamente como meio prático de orientação, a consciência histórica processaria as tradições e as heranças da experiência do passado vivas no presente, desmontando suas aparências de eternidade pelo desvelamento de seu caráter essencialmente histórico ${ }^{28}$. Seria um fenômeno que ocorre no interior do intelecto do sujeito, portanto um fenômeno individual, mas em íntima relação com a coletividade a partir das memórias e representações que são herdadas de gerações anteriores e compartilhadas num mesmo período, ou seja, em relação com os conhecimentos que estão díspostos no interior da sociedade

Como o local em que o "passado é levado a falar" 29 - a partir das questões, carências e interesses do presente, em relação aos anseíos e expectativas ${ }^{30}$ lançadas ao futuro -, a consciência histórica articula passado, presente e futuro localizando o sujeito no tempo e no espaço. Esta memóriallembrança dos dados e experiências do passado comporia o quadro de orientação das pessoas na vida prática atual. Não seria em si a própria consciência, mas o substrato/substância desta consciência, o material que ela mobiliza de determinadas maneiras.

\footnotetext{
27 Idem.

28 ASSIS, A. A. A ciência da história como resposta racional a carências de orientação. (Resenha de Razão Histórica, de Jörn Rüsen). História Revista, Goiânia: UFG, v.9, n.2, p.331, 2004, p. 334.

29 RÜSEN, J., op. cit., 2001, p. 63.

30 Definição do autor para expectativas: “Expectativa não significa previsão no sentido de profecia. Antes, trata-se de uma esperança fundamentada" Cf. RÜSEN, op. Cit.,2007a, p. 52.
} 
A consciência histórica não é idêntica, contudo, à lembrança. Só se pode falar de consciência histórica quando, para interpretar experiências atuais do tempo, é necessário, mobilizar a lembrança de determinada maneira: ela é transposta para o processo de tornar presente o passado mediante o movimento da narrativa. A mera subsistência do passado na memória ainda não é constitutiva da consciência histórica. Para a constituição da consciência histórica requer-se uma correlação expressa do presente com o passado - ou seja, uma atividade intelectual que pode ser identificada e descrita como narrativa (histórica). ${ }^{31}$

É nesta relação entre consciência e memória que Rüsen insere também a categoria utopia. Somente a recuperação dos dados da memória não dariam conta do superávit de expectativas com relação ao futuro que derivam dos "saltos utópicos" da consciência humana ${ }^{32}$. Em outras palavras, a constituição de sentido da consciência costuma ir além das circunstâncias dadas pela vida, interpretando a realidade conforme suas intenções em construir o "inteiramente novo", o "outro", o inédito. Mesmo não encontrando respaldo ou fundamentação racional no horizonte da cultura, esta vontade humana de transcender a realidade nos sugere o pensamento utópico também como uma condicionante ao agir. Assim, a presença do passado e o desejo pelo futuro exercem influência nas interpretações e ações das pessoas no presente ${ }^{33}$.

\footnotetext{
31 Ibidem, 2001, p. 64.

32 Ibidem, 2007b, p. 136.

33 Neste ponto encontramos aproximações entre o conceito rüseniano de utopia e a expressão "horizonte de expectativas" de Reinhart Koselleck. Para o segundo autor, o passado não é o único condicionante temporal das ações que ocorrem no presente. Como numa balança, as ações presentes ocorrem em meio a uma tensão entre a presença do passado (experiências) e as expectativas de futuro. Por "horizonte de expectativas", Koselleck entende as sensações e antecipações humanas que se relacionam ao futuro, os medos e esperanças, ansiedades e desejos, apatias e certezas, inquietudes e confianças/desconfianças. E "expectativas", como a potencialidade e influência que o futuro tem em ser o rumo norte das ações que ocorrem no presente. Nesta relação passado-presente-futuro, quanto menor a presença do passado (experiências), como orientação às ações no presente, maior a influência do futuro (expectativas). 0 contrário também é válido, ou seja, haveria sociedades, ou épocas, em que a presença do passado seria tão intensa sobre o presente que limitaria as novas expectativas e sonhos com relação ao futuro. Mas isso não significa que não existiria expectativas em relação a ele. 0 exemplo citado por Koselleck se refere às novas expectativas que a Revolução Francesa inseriu no contexto europeu, exatamente pela forma como as experiências do passado foram perdendo influência sobre o presente, abrindo margem a um novo "horizonte de expectativas". Novas experiências naquele tempo-presente geraram novas expectativas. E, inversamente, "velhas expectativas" se desgastaram diante das novas experiências (Koselleck, 2006, p.326). Contudo, por mais que em algumas situações, contextos ou épocas, as "experiências do passado" contrastem com as "expectativas de futuro", como no caso específico enunciado, passado e futuro devem ser entendidos como duas categorias temporais intimamente complementares. Numa dada sociedade, a forma como o passado está distribuído, ou até mesmo o tipo de passado comumente recuperado, influencia na maneira como o futuro é projetado, sonhado e esperado. Assim, podemos imaginar que há
} 
pensamento utópico define-se pela negação da realidade das circunstâncias dadas da vida. Ele articula carências, na expectativa de circunstâncias de vida nas quais desaparecessem as restrições à satisfação dessas carências. A constituição utópica de sentido pressupõe que as condições atuais do agir são irreais e que é possível imaginar outras condições totalmente diversas. [...] Ao neutralizar, ficticiamente, as circunstâncias reais da vida, o pensamento utópico abre uma via para a orientação da existência humana, na qual representações de outras circunstâncias de vida aparecem como expressão de carências de mudança do mundo, motivadoras do agir. ${ }^{34}$

Este pensamento utópico, como orientação do agir, constrói representações da realidade social descoladas das experiências temporais concretas, uma orientação ausente de mediação. Por isso, remetem a ações cuja líberdade não se evidencia na materialidade do presente. "Utopias são, por princípío, exageradas" 35 . Enunciam mais carências (ou medos e temores) do que se poderia satisfazer sob as condições dadas - um superávit das carências com relação aos meios. São constituídas de esperanças que vão além do factível aqui e agora, sendo os "sonhos que os homens têm que sonhar com toda a força de seu espírito, para conviver consigo mesmos e com seu mundo, sob a condição da experiência radical da limitação da vida" ${ }^{6}$. Portanto, para Rüsen, um componente necessário - "uma fonte vital" - das motivações do agír.

Esta liberdade do sonho utópico (que idealiza outros futuros melhores e piores) costuma deslocar tanto o indivíduo da concretude do presente, que suas ações (ou intenções) incidem de modo deficitário sobre sua orientação existencial. Estas ações e interpretações precisam ser rearranjadas conforme a realidade da experiência, nas palavras de Rüsen, o superávit do pensamento utópico precisa ser mediado pela consciência histórica.

certa relação entre a forma como o passado está disposto na sociedade ("espaço de experiência") e como esta sociedade projeta seu futuro ("horizonte de expectativas"). Saber mais em KOSELLECK, Reinhart. Futuro Passado. Contribuição à semântica dos tempos históricos. Rio de Janeiro: Contraponto, Editora Puc-RJ, 2006.

34 RÜSEN, J., op. cit. 2007b, p.137.

35 Ibidem, p. 138.

36 Idem. 
Com isso, o pensamento histórico entra no jogo. Por definição, ele é crítico da utopia, pois conecta o superávit intencional do agir humano às experiências acumuladas do que esse agir causou ou não ao longo do tempo. As experiências exageradas, com as quais as utopias sonham com o reino da liberdade, são por ele submetidas ao regime da necessidade, imposto pela força domesticadora da memória, que recorda o que foi o caso. Ele modera as constituições utópicas de sentido, a fim de fornecer uma base sólida às representações do que teria sido o caso, sem a qual estas não seriam fatores da orientação do agir. ${ }^{37}$

Contudo, para Rüsen, não se trata de menosprezar este superávit de intenção e de esperanças em nome das experiências e conhecimentos do passado. Mas antes, de questionar estas intenções para que possam se tornar possíveis como orientação no âmbito prático das ações humanas - "a utopia vazia de experiência torna-se uma alteridade plena de experiência" ${ }^{38}$. É nesta relação tensa entre experiências e expectativas, ou entre história e utopia que a orientação existencial se dá no cotidiano. A utopia como crítica da história, na busca por um outro futuro (bom ou ruim), e o conhecimento histórico como uma mediação nas possíveis intenções "exageradas" da consciência utópica.

\section{narrativa histórica e formas de recuperar o passado}

Nos procedimentos de fala ou escrita, onde se utilizam palavras para organizar frases, sentenças, constituir um conjunto de ideias, elaborar um raciocínio, uma opinião, defender um argumento, a linguagem teria a propriedade de organizar e apresentar o pensamento, sendo o meio pelo qual as consciências histórica e utópica se expressam. Para Rüsen, a narrativa é um dos fundamentos da ciência da história, em sua maneira particular historiográfica de expressar os resultados das pesquisas, e também fundamento pelo qual as pessoas entram em contato com os conhecimentos históricos do cotidiano, com as memórias, representações e tradições herdadas.

\footnotetext{
37 Ibidem, p. 139.

38 Ibidem, p. 142.
} 
Dentre as narrativas enunciadas pelo sujeito, na intenção de distinguir a narrativa fíccional da narrativa "histórica" ${ }^{\text {"39. }}$. Rüsen propõe a necessidade dela atender a três especificações: deve recorrer a lembranças de experiências de mudanças temporais passadas do homem e de seu mundo para interpretar as experiências do tempo presente; deve articular de forma interdependente passadopresente-futuro numa representação de continuidade, mantendo um sentído entre as ações do passado e as expectativas e intenções de futuro; e deve colaborar na instituição da identidade do sujeito, localizando-o no fluxo do tempo ${ }^{40}$. Desta forma, temos uma narrativa histórica enunciada pelo sujeito que retorna para ele (narrador), atribuindo sentido e significado ao presente. Martins (2012) colabora neste entendimento ao apontar que

\begin{abstract}
a enunciação narrativa - própria ao pensamento discursivo - está intimamente conectada à sequenciação temporal que ocorre no circuito constante de experiência-reflexão-historicizaçãoenunciação. Isso significa que o sujeito agente sistematiza, consolida, instrumentaliza a experiência vivida (do passado) no enunciado narrativo instituidor de sentido, com o fito de firmarse no fluxo do tempo (presente) e de orientar-se para a etapa subsequente (perspectiva de futuro). ${ }^{41}$
\end{abstract}

Pela narrativa histórica os homens contam as suas vidas, explicam-se e instituem-se como pertencentes ao mundo, percebem a presença do passado no presente, historicizando a si próprios e também as suas culturas, tradições, regras e valores. Nas palavras de Pacievitch ${ }^{42}$, seria possível inferir que as tomadas de decisões de cunho ético e moral, ações individuais ou coletivas e a formação de identidades estariam diretamente ligadas ao modo como as pessoas organizam suas narrativas históricas. Desta forma, haveria uma relação entre a instituição de identidades no presente e o modo como a consciência histórica recupera e interpreta os dados do passado e exprime em forma de narrativa.

\footnotetext{
${ }^{39}$ Haveria uma forma alternativa de expressar a operação da consciência histórica que não pela narrativa? Talvez pela linguagem artística, mas Rüsen não desenvolve esta possibilidade, apenas a deixa em aberto (RÜSEN, 2001, p. 61).

${ }^{40}$ Ibidem, p. 62-66.

${ }^{41}$ MARTINS, E. R., op. cit., p. 68.

42 PACIEVITCH, C. Consciência Histórica e Identidade de Professores de História. Ponta Grossa, 2007. (Dissertação de mestrado em Educação), UEPG, Ponta Grossa, 2007, p. 57.
} 
Em sua análise, no intuito de escapar de uma perspectiva possivelmente relativista e subjetivista, Rüsen nos sugere que, para além da interpretação/mobilização individual do sujeito, há um possível sentido prévio "protonarrativa" - existente no interior da cultura que influencia na operação da consciência histórica dos sujeitos. Nos próprios feitos do presente haveria uma espécie de "pré-história", capaz de constituir o sentido da narrativa histórica, no qual - passado ainda não é consciente e estaria ativamente presente na vida prática das pessoas. Deste modo, a ação humana ocorreria a partir de pressupostos, e em cada ação se encontrariam elementos de outras ações anteriores.

Em uma pré-história desse típo o passado praticamente se ofereceria a ser lembrado no presente, apresentando-se - ainda antes de ser, como passado, conscientemente tornado presente pela narrativa - como uma espécie de forma pré-passada (isto é, ativamente presente na vida prática), de protonarrativa em que se baseia qualquer narrativa histórica." ${ }^{43}$

No interior da teoria rüseniana, este passado vivo no presente como forma de orientação é definido na expressão tradição ${ }^{44}$. Rüsen nos sugere que as interpretações das pessoas no presente, ou as formas como elas agem em seus cotidianos, em certa medida, estão em relação com os sentidos existentes no interior destas tradições. Deste modo, a consciência histórica individual se relaciona com estes dados imediatos da cultura, recuperando-os, de forma a possibilitar um quadro interpretativo mínimo no entendimento da realidade.

Contudo, estaríamos resumindo as operações da consciência caso afirmássemos ser sua função recuperar unicamente os dados da tradição. Em alguns momentos, estes dados precisam ser criticados e refutados, por não serem suficientes em orientar ou explicar o presente ${ }^{45}$. Em meio a mudanças repentinas, situações de traumas, descontentamentos, circunstâncias inéditas, o agir humano busca ir além destes dados, recuperando o passado de forma variada. Para Rüsen,

\footnotetext{
43 Ibidem, p. 76.

44 Idem.

45 Aqui encontramos pontos de contato entre o pensamento de Rüsen e do filósofo alemão Friedrich Nietzsche. Saber como o homem se relaciona com o seu passado, e em que medida ele pode se tornar maior ou menor nesta relação, parece ser a tônica do discurso nietzschiano presente em sua obra sua obra Segunda Consideração Intempestiva. Haveriam situações em que a história é pertinente ao vivente, contudo, ao mesmo tempo em que libertaria/conduziria o indivíduo às ações no presente, quando dosada em excesso, a História viria a cumprir um papel exatamente contrário.
} 
criticar a tradição é importante por possibilitar novas interpretações sobre este passado que está disposto inconscientemente no presente, seja nas condições que (im)possibilitam o agir (instituições ou condições econômicas), nos conjuntos de ideias compartilhadas (memórias, ritos culturais, ideologias), ou até mesmo nas interpretações dos vestígios históricos materiais (monumentos, esculturas, objetos enterrados). Um processo que desvela o passado, tornando-o consciente enquanto tal, atribuindo-lhe qualidade temporal própria, que o distancia do presente. Assim, esta problematização da tradição se dá em meio a uma situação cultural de desestabilidade, ou seja, um contexto desafiador que remete o indivíduo a uma situação de "crise" de orientação cultural

Haveriam três tipos possíveis de crises ${ }^{46}$ : crise normal, crise crítica e crise catastrófica. Mesmo estando representadas separadamente, no sentido weberiano de tipos ideais, podem ocorrer em formas mistas no interior da sociedade. De modo sintético, podemos definir como "crise normal" um dado acontecimento que é explicado no sujeito a partir de elementos culturais previamente dados. Os padrões de significância da crise já estão dados pela cultura, ocorrendo, apenas, um reordenamento de elementos já desenvolvidos e compreendidos. Já no caso de uma "crise crítica", a resolução/compreensão só ocorre diante da inserção de novos elementos, transformando o potencial de orientação de sentido previamente existente na cultura histórica. Nesse caso, novos padrões de significados são criados pela consciência histórica no processo de interpretação da realidade. No referido especificamente ao pensamento histórico comum e a vida cotidiana, podemos exemplificar com o caso de um sujeito que se vê diante de um acontecimento cujo horizonte próprio de explicações não dão conta de explicar/compreender, e precisa necessariamente inserir um novo elemento (criado ou estrangeiro) na explicação cultural. Por fim, por "crise catastrófica" se entende as situações que ocorrem de maior intensidade, na qual a própria consciência histórica se vê impossibilititada de (re)organizar interpretações existentes ou articular/criar novas. Como resultado, a narrativa histórica se silencia no que se refere à proposição de um sentido histórico, iniciando um período que pode ser entendido como "traumático", onde a linguagem não dá conta de atríbuir sentido e inteligíbilidade ao ocorrido. Uma reorganização da cultura, a longo prazo, será necessária para que novos elementos sejam inseridos e novas interpretações sejam possibilitidadas.

\footnotetext{
${ }^{46} \mathrm{Na}$ trilogia Grundzüge einer Historik (Fundamentos de uma teoria da história) o conceito de crise não está presente. Ele aparece posteriormente no texto Como dar sentido ao passado. Questões relevantes de meta-história, publicado no Brasil em 2009. Muito embora este conceito se relacione especificamente às implicações de uma memória pós-holocausto na Alemanha, quando isolamos as contribuições individuais deste conceito, no interior do referido texto, percebemos que ele também colabora no entendimento dos Fundamentos de uma teoria da história, ao melhor articular os conceitos de tradição e consciência histórica: a situação de crise pode levar o indivíduo a criticar/questionar os dados da tradição.
} 
Com o conceito de crise podemos perceber que o trabalho da consciência histórica, além de ser resultado do superávit de intenção que vai além dos dados da tradição, é também mobilizado diante dos contextos desafiadores que provocam no sujeito uma crise de orientação, de questionamento dos padrões culturais de explicação. Assim, recuperar os dados do passado a partir da memóría e articular com a manutenção da identidade no presente, tem a ver com a vontade humana de ir além do que é o fato, entender-se diante das mudanças e solucionar os problemas de crise de orientação.

Para Rüsen, este processo de rememorar o passado não se faz de forma uniforme no sujeito, mas de quatro maneiras distintas e complementares, entendidas como "tipos de geração de sentido"47, "constituição de sentido"48 ou "tipologias da consciência histórica" 49 . Estas formas de recuperação implicam em tipos de narrativas e também de identidades. Estas quatro maneiras seriam: modo tradicional, exemplar, crítico e genético.

Por modo tradicional, Rüsen se refere a operação da consciência que se faz a partir de dados da tradição, como anunciado de modo breve acima. A consciência estaria repetindo o modelo cultural vigente, especialmente as informações estáticas, atemporais, ritualísticas, uma explicação do mundo a partir de discursos mitológicos e discursos de origem, que buscam resistir às mudanças e se afirmar no tempo.

A identidade que se forma a partir desta operação tem enraizada em suas atitudes, as motivações e modelos de percepção e interpretação das formas sociais mais tradicionais da subjetividade, modelos de comportamento estáticos, dogmáticos, que se julgam corretos e únicos desde sempre. Identidades que, no âmbito coletivo, vinculam-se a uma ideia atemporal de "nós", uma "comunidade permanente de valores" que busca se fundamentar em "pré-histórias comuns" às circunstancias dadas da vida e na noção de destinos compartilhados. Em meío às relações e comunicações cotidianas, este modelo de identidade produz discussões estéreis entre culturas e papéis sociais divergentes, por não viabílizar necessariamente a argumentação das ideias, nem o aceite de opiniões contrárias, já que se apresentam a priori como inquestionáveis. $\bigcirc$ critério de sentido determinante para esta forma de constituição narrativa é o enraizamento do ordenamento da vida e do mundo na profundeza inconsciente de um tempo atemporal.

\footnotetext{
47 Ibidem, 2001.

48 Ibidem, 2007a.

49 RÜSEN, J. El desarrollo de la competencia narrativa em el aprendiaje histórico. Una hipótesis ontogenética relativa a la conciencia moral. Revista Propuesta Educativa, Buenos Aires, Ano 4, n. 7, p. 27-36. oct. 1992.
} 
De maneira diversa, o modo exemplar se refere a operação da consciência em direção ao passado na busca por regularidades, princípios, padrões de comportamentos, regras, exemplos que podem ser aplicados satisfatoriamente ao presente e colaborar na orientação. Neste processo, as determinações de sentido tomam uma forma abstrata, não aparecendo mais como realidades concretas da vida prática, mas são pensadas como regras gerais do agir. $O$ sentido recuperado busca artícular os fenômenos na supratemporalidade dos princípios e das regras.

Essa forma possibilita estipular conscientemente e sistematicamente como os homens podem ou devem agir em determinadas situações ou sob determinadas condições. Uma recuperação do passado que se apresenta como um exemplo ao presente. Não se trata mais da imutabilidade de padrões a serem seguidos, ou de um trabalho da consciência para recuperar no passado a essência das coisas, comportamentos e ideias. Mas de recuperar regras gerais a partir de casos partículares, que estão abertas a questionamentos de juízo no presente desde que fundamentadas em novas regras a partir de novos casos. Para Rüsen, esta maneira de operar a consciência atribuiria à identidade o caráter de provisoriedade, passível de críticas à luz de princípios. Ela ultrapassaria os limites da atribuição tradicional dos papéis sociais, ao assumir a auto fundamentação a partir de princípios gerais. Quem sou ou quem somos nós depende de nossa capacidade de realizar/vivenciar os princípios de ordenamento da vida que se consideram obrigatórios em geral ${ }^{50}$. Sobre esta forma de identidade, que elege regras gerais como parâmetro, Rüsen aponta-nos a seguinte crítica:

[.] em toda forma de identidade constituída tradicionalmente está presente uma dose de dogmatismo, na medida em que a limitação e a particularidade das tradições constituintes de identidade são sempre tomadas pelo todo e pelo próprio, de modo que desvios só podem ser sancionados negativamente. Esse dogmatismo se transforma no tipo de constituição exemplar de sentido, ao ultrapassar os limites para o abstrato-geral. Transforma-se ainda na arrogância de princípio, que atribui à sua própria vida a dignidade de ser manifestação por excelência da regra geral e tende a ver em outros modos de vida formas mais fracas ou fracassadas. ${ }^{51}$

\footnotetext{
50 Ibidem, p. 53.

51 Idem.
} 
Por modo crítico, Rüsen entende a operação da consciência histórica que busca criticar os atuais modelos de interpretação culturalmente influentes a partir de rearranjos das experiências do passado. Novos modelos de interpretação são criados, "interpretações alternativas", que buscam questionar as "circunstancias atuais da vida", e as perspectivas de futuro da vida que delas decorrem. Recupera-se do passado novos dados, ou sobre os mesmos incidem novas interpretações, de tal forma que crenças atuais, comportamentos, costumes, padrões explicativos são fragilizados, abalando seus fundamentos de plausibilidade, ou até mesmo são substituídos. Desestruturando narrativas, rompendo constructos categoriais, destruindo conceitos, símbolos, modelos de interpretação, o modo crítico de sentido tem como característica a ruptura da continuidade, da permanência.

No âmbito da identidade, com a força da negação, os sujeitos ganham domínio sobre si mesmos, oferecendo resistência às tentativas de dominação cultural. Exatamente porque compreendem os inúmeros exemplos/padrões contidos na história - que podem (ou não) ser reivindicados como regras ao presente -, que escolhem conscientemente criticar qualquer permanência ou reivindicação de modelos explicativos que reforcem estas continuidades. Distanciando-se dos sentidos e interpretações preexistentes no cotidiano, como também criticando a conformidade que algumas mudanças temporais trazem em si, os sujeitos ganham fôlego para modelar culturalmente seu próprio tempo, da maneira que creem poder, por meio da memória histórica.

E, por fim, o modo genético de recuperar o passado diz respeito a uma forma particular de mobilizar os dados da memória, as experiências do tempo, prevalecendo no presente a ideía positiva da mudança temporal, como qualidade fundamental do ser humano no tempo e no espaço.

As experiências do passado, quando compreendidas sob a perspectiva das mudanças temporais, possibilitam um entendimento do presente como um momento histórico provisório, que está em desenvolvimento, evolução permanente. Deste modo, o futuro não se apresenta como estático, ou previsível a partir de regras, mas como uma possibilidade a ser construída, um vir a ser.

Para além da submissão comum a sistemas de regras e princípios, e também da distinção crítica e contraposição, o modo genético de recuperar o passado e de elaborar o pensamento permite que o sujeito perceba em si e no outro as qualidades da alteridade, os modos do ser outro e utilizar essa percepção como chance de consolidação da identidade pelo reconhecimento. Deste modo, nas palavras de 
Rüsen, a mudança pode ser afirmada, vivenciada e reconhecida como uma qualidade positiva da subjetividade ${ }^{52}$.

Reconhecer a mudança histórica como fundamento, como perspectiva e maneira de interpretar os dados do passado, amplia a comunicação intercultural no presente por possibilitar um entendimento das outras tradições culturais como essencialmente históricas, não submetendo-as a abstrações, regras ou discriminações à priori. A diversidade é compreendida como possibilidade, sem, para isso, implicar em homogeneizações.

Pela rememoração das experiências históricas, sob esta perspectiva da mudança, abrem-se aos sujeitos a chance da individuação, tanto no âmbito pessoal como coletivo (grupos, sociedades e culturas). Isso não significa a instituiç̧ão extremada do individualismo, como postulado pela pós-modernidade. Mas antes, a proposição de comunicações interculturais, que considerem novas formas de subjetividade na construção argumentativa do consenso e uma ideia de coletividade que contenha em si a premissa da diversidade.

Uma consciência histórica que opere a partir de noç̃̃es temporais como processo, evolução e mudança gera como produto uma identidade compreendida como fenômeno social e cultural em transformação. Como sentido, o tempo é temporalizado e este modo de reivindicar os dados do passado constroem a percepção no presente de que a realidade - compreensão do indivíduo sobre a coletividade e si próprio - está em mudança, podendo ser outra coisa, nas palavras de Rüsen, "ser por sí mesmo é uma determinação, uma diretriz da mudança do que se é. Lembrar-se daquilo que era e de como se tornou o que é, faz plausível, para o sujeito, tornar-se outro" 53 .

Como um fenômeno individual ${ }^{54}$, convém apontarmos que há uma certa graduação na complexidade destas tipologias. Esta complexificação ocorre na medida em que cada tipologia posterior contém em si as anteriores. Analisando especificamente a narrativa historiográfica, indicando na expressão topoi complexo, Rüsen aponta para a possibilidade destas tipologias coexistirem e implicarem-se mutuamente,

\footnotetext{
52 Ibidem, p. 60.

53 Idem.

54 RÜSEN, J. Jörn Rüsen e o ensino de história. (Org. Maria Auxiliadora Schmidt, Isabel Barca e Estevão de Rezende Martins). Curitiba: Ed. UFPR, 2010, p. 63.
} 
[...] um [tipo] não pode ser pensado sem os demais. Ademais, sob condições determinadas, a passagem de uns aos outros não se faz de modo arbitrário. $\bigcirc$ contexto da implicação significa que os elementos formais dos quatro tipos aparecem conjuntamente em toda formatação historiográfíca. Sua ponderação não é, naturalmente uniforme, mas dá-se em mesclas variáveis, sem que isso impeça reconhecer com clareza que elementos essenciais de um tipo estão relacionados a elementos análogos dos demais tipos. [...] Essa tensão [entre as tipologias] pode ser descrita, abstratamente, como uma tendência do tipo da constituição tradicional de sentido, de transmutar-se em exemplar, e do tipo exemplar, de transmutarse em genético. $\bigcirc$ tipo da constituição crítica de sentido funciona como o meío e o catalizador da transição. Ao longo dessas transmutações, aumentam o conteúdo experiencial da historiografia e a complexidade da interpelação dos sujeitos, a que interessa diretamente o teor da identidade histórica. ${ }^{55}$

Quando atentamos especificamente ao pensamento histórico comum, podemos aproximar o entendimento complexo acima - e sua ideia de graduação e interdependência das tipologias -, da seguinte maneira: para construir uma imagem positiva da mudança como forma de orientação ao presente, no referido a algum assunto específico, o sujeito deve também estar em condição de aceitar que críticas à modelos, padrões ou regras gerais, são necessárias ao processo de desnaturalização do mundo, dos costumes e das tradições - um entendimento evolutivo do homem no tempo. Para alguns assuntos, o pensamento histórico pode vir a operar de modo tradicional, enquanto que para outros, de modo genético. Este sujeito não habitaria de modo permanente nestas formas de geração de sentido, e sua interpretação da realidade e, consequentemente, ações no cotidiano estão relacionadas à esta somatória de formas concomitantes de recuperar o passado.

Exemplificando, uma pessoa pode operar de modo genético os dados do passado quando questionado sobre o racismo no Brasil, mas pode não fazer o mesmo quando o assunto for o mercado de trabalho e os direitos das mulheres. Ou recuperar de modo crítico os dados da memória para refutar alguma situação no presente que remeta à padrões culturais paternalistas, mas agir de modo tradicional diante de uma discussão política. Inclusive, existe a possibillidade do sujeito operar de modo tradicional e defender suas crenças religiosas num ambiente de diálogo entre pares, e neste mesmo diálogo também mobilizar geneticamente a consciência para explicar as mudanças históricas na referida instituição religiosa.

\footnotetext{
55 Ibidem, 2007b, p. 64.
} 


\section{cultura histórica e formação histórica}

Já como um fenômeno coletivo, dando continuidade à discussão anterior, por mais que nos abstenhamos anteriormente em apontarmos a consciência histórica como uma prerrogativa do presente (ou da modernidade), convém assumirmos que ela está em diálogo com uma cultura mais ampla, que atualmente se relaciona de modo íntimo com a disposição crescente do conhecimento científico no interior da sociedade - além das memórias, tradições e representações herdadas. Podemos apontar que a cultura histórica no presente diverge das anteriores (do passado) por conter em si um sistema mais eficiente de meios de comunicação de massa (televisão, rádio, revistas, internet, livros, cinema), produtos de uma indústria cultural com maior amplitude de circulação, além de conter em si um contexto social de maior acesso universitário e produtos e eventos que derivam do conhecimento histórico científico (teses, dissertações, artigos, revistas, revistas online, congressos, palestras, entrevistas, documentários, etc). Por isto mesmo, não convém imaginarmos a cultura histórica como uma cultura homogenia, da humanidade ou de uma época - dada a forma desigual como esses produtos da cultura e dados da memória se distribuem no interior da sociedade -, mas antes como nichos de cultura que se marcam e delimitam pelo momento e lugar, numa combinação entre os arranjos herdados do passado e as criações do presente.

Com a expressão cultura histórica, Rüsen busca deixar claro que o especificamente histórico possui um lugar próprio e peculiar no quadro cultural de orientação para a vida humana prática. Seriam as "imagens históricas" presentes no agir cotidiano das pessoas, a totalidade daquilo que se refere ao passado, que permeia uma dada sociedade no presente e que de certo modo colabora na orientação ${ }^{56}$. 0 professor Bodo von Borries sintetiza esta conceituação na afirmação: "quando se fala de produção e apresentação, mas também de consumo e comunicação de e sobre

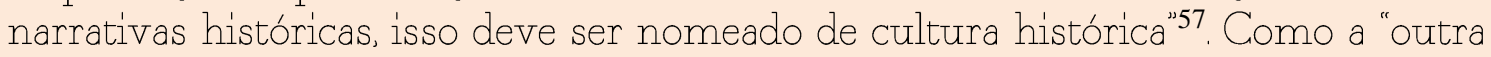
face da moeda, da consciência histórica"58 - um entendimento da cultura como práxis desta consciência -, a relação entre estes conceitos seria então uma relação dialética: a consciência histórica se desenvolve como um "constructo individual", durante processos de internalização e de socialização e a cultura histórica se desenvolve no processo oposto, de externalização e de objetivação. Assim, a partír destas objetivações da consciência teríamos um cotidiano recheado de "imagens" herdadas do passado, ou produzidas no presente, numa espécie de arquitetura de ideias, memórias, representações, signos e símbolos.

\footnotetext{
56 RÜSEN, J., op. cit., 2009, p. 172.

${ }^{57}$ BORRIES, B. V., op. cit., p. 19.

${ }^{58}$ CARDOSO, O., op. cit., p. 159.
} 
Derivando dos fatores (1) pensar, (2) sentir, (3) querer, (4) valorizar e (5) crer, a cultura histórica pode ser compreendida a partir de cinco dimensões: uma dimensão cognitiva, caracterizada pela presença do saber e do conhecimento científico, relacionada a critérios de pertinência, verdade, fundamentação empírica e de teor normativo; uma dimensão estética, relacionada à percepção das apresentações do passado (nos diversos meios), que se relaciona a critérios de sensíbilidade, beleza, agradabilidade, atração; uma dimensão política, que se refere à potencialidade de se atrelar a jogos de poder, de ser instrumentalizada, servir a interesses, apresentar "eficácia" política: uma dimensão moral, que se caracteriza pela incidência das normas éticas e morais do presente sobre as representações/produtos relacionados ao passado, atrelando-se a critérios de bondade e maldade, justiça e injustiça; e uma dimensão religiosa, que procede das "profundezas" da subjetividade humana, vinculando-se ao sentido último da vida, quando as ideias históricas se apresentam, ou são interpretadas, no presente, a partír de critérios transcendentais, teleológicos, remetendo a noções tais como salvação, morte, céu, inferno, espiritualidade ${ }^{59}$. Estas cinco dimensões, analiticamente distinguíveis, estariam entremeadas na prática concreta da vida.

Num exemplo hipotético, podemos reelaborar estes apontamentos de Rüsen da seguinte maneira: as informações históricas sobre a América Latina estão dispostas de modo variado no interior da sociedade (produções cinematográficas, novelas, dramas históricos, poemas, músicas, noticiário jornalístico televisivo e impresso, entretenimento de internet, manuais didáticos, representações herdadas e compartilhadas, objetos, artefatos, eventos culturais, legislações, discursos políticos, etc.), que buscam se apresentar "racionalmente", sob "bons argumentos", reivindicando a pretensão da verdade, sensibilizando e buscando convencer pela estética e oratória, podendo estar envolto a relações de poder, legitimando causas políticas ou causas sociais ${ }^{60}$.

De modo complementar, para Ronaldo Cardoso Alves, a consideração dos papéis do Estado e do Mercado também colaboram no enriquecimento do entendimento da cultura histórica:

\footnotetext{
59 Ibidem, 2015b, p. 229.

60 Como exemplo da dimensão religiosa da cultura histórica, podemos inserir o fenômeno recente de “diabolização" da América Latina por uma parcela significativa da sociedade brasileira, que, enviesada por um posicionamento político de extrema direita, de ideologia neoliberal, rechaça a América Latina em virtude do alinhamento recente de muitos dos países aos partidos de esquerda. Este posicionamento mistura política e fim dos tempos, com um olhar religioso sobre os acontecimentos políticos, satanizando e excluindo os atores políticos, grupos e simpatizantes.
} 
De um lado, a relação com o Estado, seja pelo envolvimento de pais e fillhos com a educação escolar, seja na utilização (ou não) dos espaços culturais e de lazer por ele proporcionado (ou não); de outro, a influência do Mercado, seja via utilizzação de espaços privados, seja via meios de comunicação (aqui o Estado também atua). A estética, a política, a cognição e a ética se colocam como dimensões da cultura histórica que, influenciadas pelo Estado e pelo Mercado, prescrevem modelos, impõem identidades a serem reproduzidas por todas as pessoas e também pelos estudantes e suas famílias. 61

Desse modo, o conceito de consciência histórica está implicado no conceito de cultura histórica de tal forma que podemos afirmar que não se trata do agir de uma estrutura sobre o sujeito, no sentido determinista, mas de uma estrutura da qual o sujeito extrai e interpreta os elementos fundamentais de sua orientação - "as práticas sociais que se ligam à subjetividade da consciência"62. Enfatizando especificamente a importância da memória para a cultura ${ }^{63}$, Estevão Chaves de Rezende Martins sistematiza da seguinte maneira esta relação entre vontade individual de ação e a cultura histórica como condição estruturante.

Como práxis da consciência, essa cultura requer a subjetividade humana, e mesmo a fomenta. Essa cultura se constitui pela cadeia da memória. A memóría tem, certamente, duas acepções: a correspondente à memóría pessoal, à lembrança partícular do indivíduo, e a referente à cultura, constituída pelo conjunto da evolução temporal da sociedade e dos vestígios que, nela, foram conservados para além de seus respectivos momentos presentes. caráter histórico reside na função constitutiva da memória para a identidade dos indivíduos e de suas respectivas comunidades [...] A cultura se reveste, pois, da característica de uma suma da natureza racional humana, que se exprime na interdependência entre apropriação interpretativa do mundo pelo homem e

${ }^{61}$ ALVES, R. C.. Da Consciência Histórica (Pré) (Pós?) Moderna: reflexões a partir do pensamento de Reinhart Koselleck. Saeculum, João Pessoa: UFPB, v.30, p.321-339, 2014, p. 172.

${ }^{62}$ CARVALHO, R. G. Jörn Rüsen e os fundamentos teóricos da didática da história (resenha). Revista de Teoria da História, v.11, p.358-368, 2014, p. 263.

${ }^{63}$ Para Estevão Chaves de Rezende Martins, a memória histórica desempenharia um papel decisivo na construção da identidade, sendo a cultura histórica - genérica ou formal - um produto da consciência histórica, aproximando-se (ou contida no interior) do conceito amplo de memória histórica (MARTINS, 2012, p.75). 
afirmação da autonomia subjetiva do homem. A cultura histórica é, então, a artículação de percepção, interpretação, orientação e teleologia na qual o tempo é um fator determinante da vida humana. ${ }^{64}$

Assim, complementando os apontamentos anteriores, Martins colabora ao indicar o entendimento da cultura histórica como uma grandeza específica da cultura que se refere às tradições históricas, modelos, padrões e crenças que precedem o indivíduo (ou a coletividade) no presente e que se ligam a ele (ou a coletividade) a partir destas "cadeias de memórias" e "vestígios do passado" deixados no presente e também construídos por ele.

conceito de cultura histórica, deste modo, avança para além do conceito de tradição ao sintetizar elementos materiais e imateriais da cultura, tomados conscientemente e inconscientemente pelo sujeito, numa demarcação que vai além dos ritos e verdades atemporais" e "absolutas". A cultura histórica como a suma dos conhecimentos históricos (comum e científico) dispostos no interior da sociedade. Deste modo, convém entendermos a tradição como um dos sentidos internos que estão dispostos e disputam espaço no interior da cultura.

Como vimos anteriormente, a partir das formas de recuperação do passado, estes "sentidos" podem ser reafirmados, questionados, problematizados e historicizados conforme as carências e interesses dos sujeitos: o que os qualifica, ao mesmo tempo, como produto e produtores da cultura histórica. Assim, a cultura histórica não se situa como elemento absolutamente superestrutural, nem como mero reflexo da infraestrutura, necessitando ser apreendida no e a partír de processos relacionais ${ }^{65}$.

Como gesto educativo - Rüsen utiliza do termo formação histórica -, este constructo cultural da cultura incide cotidianamente sobre a (re)interpretação dos sujeitos colaborando na formação de seus pensamentos históricos. Complementando as discussões anteriores sobre a singularidade do conhecimento científico na orientação cultural da sociedade - possivelmente Rüsen está se referindo ao modelo ocidental de sociedade -, haveriam duas formas da cultura

64 Ibidem, p. 73.

${ }^{65}$ SCHMIDT, M. A. M. S. Cultura histórica a aprendizagem histórica. Revista Nupem, v. 6. n.10, p. 31-50, 2014, p33. 
colaborar na formação do sujeito, definidas conceitualmente como compensatória e complementar ${ }^{66}$.

A formação é compensatóría quando, acriticamente, de fora da produção científica do saber ou contra ela, deixa-a ao sabor de suas próprias regras, separa da racionalidade intrínseca ao saber científico as carências de orientação voltadas ao todo, à relação à vida e à subjetividade, enfim, satisfaz essas carências com meios não científicos. Nesse caso, é a arte a mais utilizada, comprometendo irreversivelmente a dimensão cognitiva da compreensão humana do mundo e a auto-interpretação dos homens. [...] Formação pode dar-se ainda de modo complementar. Trata-se de fazer adotar seus próprios pontos de vista nos saberes científicos e em sua produção pelas ciências. Isso só é possível mediante a reflexão sobre as regras e os princípios com que as ciências organizam categorialmente sua relação à experiência, à práxis e à subjetividade. [.". Elas [essas reflexões] instituem, para os sujeitos envolvidos na produção e na utilização dos saberes, uma possibilidade de comunicação, na qual as diversas competências para produzir entendimento sobre as interpretações e o manejo dos problemas comuns são adquiridas. Nesse trabalho de entendimento são afastados os limites do saber, saberes são integrados, possibilidades de orientação cognitiva da práxis adquiridas e testadas, subjetividade para o autoconhecimento e entendimento mútuo fortalecida. ${ }^{67}$

De modo sintético, a formação compensatória diz respeito às informações históricas "não científicas" que estão dispostas na sociedade e orientam as pessoas no cotidiano, como já exemplificamos anteriormente. Por não apresentarem o rigor da metodología científica como fundamento, segundo Rüsen ${ }^{68}$, auxiliam com um menor ganho qualitativo as orientações e identificações no presente. E, por formação complementar, Rüsen se refere aos conhecimentos históricos científicos que retornam como orientação à sociedade, sejam como produtos, discursos públicos ou educação formal/institucional (sistema de educação básica, universitária e cursos de formação). Uma divisão instrumental que colabora no entendimento do pensamento histórico ao dar visibilidade à função didática da ciência da história. Esta divisão também possibilita distinguir história de memória no interior da

${ }^{66}$ RÜSEN, J., op. cit., 2007a, p. 96.

${ }^{67}$ Idem.

${ }^{68}$ Idem. 
cultura histórica, ou distinguir a própria memória da cultura histórica, que em alguns casos podem se assemelhar. Segundo Rüsen, dependendo de quanto se estenda o arco da memória, ele ou abarcará o campo da cultura histórica em toda a sua amplitude ou circunscreverá apenas o passado vivo na consciência dos indivíduos. Para o autor, convém limitar o alcance da memóría ao ponto de distingui-la do conhecimento histórico regulado metodicamente, o qual também participa da cultura. Enquanto que a memória torna ou mantém atual o passado, a história o colocaria na distância da diferença temporal, conferindo-lhe traços de alteridade, de diferenciação para com o presente.

A memória seria espontânea, subjetiva, carregada de emoções, motivadora das ações, seguindo critérios estético-retóricos de aceitação, manipulando as experiências segundo anseios e interesses práticos. E a história - Rüsen atríbui ressalvas a esta classificação instrumental -, como contraponto, seria artificial, "mais objetiva", marcada pela regulação metódica, com um potencial menor para mobílizar as ações na sociedade (em razão da forma e público alvo), seguidora de critérios de pertinência empírica e manipuladora das experiências segundo as coerções da racionalidade argumentativa ${ }^{69}$. Portanto, apesar de históría e memóría se imbricarem mutuamente - o que tornaria impossível uma distinção radical entre as duas -, no interior da cultura histórica o conhecimento histórico científico qualifica e participa de maneira diferente da orientação para a vida prática, mas não de modo puro, por vez, se mesclando aos dados da memóría.

Neste sentido, avançando e concluindo nossa discussão, esta arquitetura de informações históricas incide sobre o indivíduo não de maneira totalmente pronta e determinante, mas condicionada por um processo próprio de interpretação dos sujeitos em meio às relações sociais. Quem desenvolve este apontamento é o professor Estevão de Rezende Martins ${ }^{70}$, tradutor e comentador nacional de Rüsen, que neste momento complementa o entendimento ao teorizar sobre os processos de historização do pensamento no interior da cultura.

Nesta relação dialética, o pensamento se historiciza na medida em que gradativamente organiza a sequência e a dependência das ocorrências experimentadas pelo sujeito ao longo da vida, colocando-as em perspectivas de longo, médio e curto prazos. Martins se refere a este processo de construção das abstrações temporais em meí ao cotidiano como "apropriação reflexiva do tempo". Essa construção gradual do passado no pensamento, que se dá em meio as formações compensatórias e complementares, relaciona-se à potencialidade do sujeito no presente de perceber e criticar a inércia do tempo, tornando gradualmente

69 RÜSEN, J., op. cit. 2015 b, p. 222.

70 MARTINS, E. R., op. cit. 2011, p. 47. 
- passado presente no presente consciente enquanto tal. Essa construção de tomada de consciência do meio ambiente cultural em que o indivíduo emerge,

pode ser comparado com um sistema de círculos cujo centro é a subjetividade particular do indivíduo. Esse centro é suposto como o de um agente racional humano conformado segundo as características físicas e mentais normais. $\bigcirc$ ponto focal é o indivíduo, agente consciente e racional (e somente nessa condição). [...] $\bigcirc$ primeiro círculo corresponde à primeira fase temporal de contato entre o sujeito e o legado histórico da cultura. Nesse círculo, habitualmente, encontram-se as relações familiares, o aprendizado da linguagem, o treinamento comportamental, a transmissão dos valores elementares vigentes no respectivo espaço social. Os fatores enfeixados nesse primeiro círculo costumam ser ordinariamente estudados pela psicologia do desenvolvimento infantil. Não são diretamente refletidos pela ciência histórica, mas é profícuo tê-los presentes, na medida em que as tradições mentais, as constantes culturais e os hábitos sociais amiúde revelados pela pesquisa (notadamente na história oral) apontam para os processos de formação dos agentes desde seus primeiros momentos de socialização. Trata-se de uma fase de instrução, de educação informal, de constituição individual e comunitária do sujeito consciente, como indicam os círculos subsequentes. ${ }^{71}$

\section{${ }^{71} \mathrm{Idem}$.}


Figura 3: A interseção e a interdependência das diversas etapas da convivência social e do aprendizado - formal e/ou informal ${ }^{72}$.

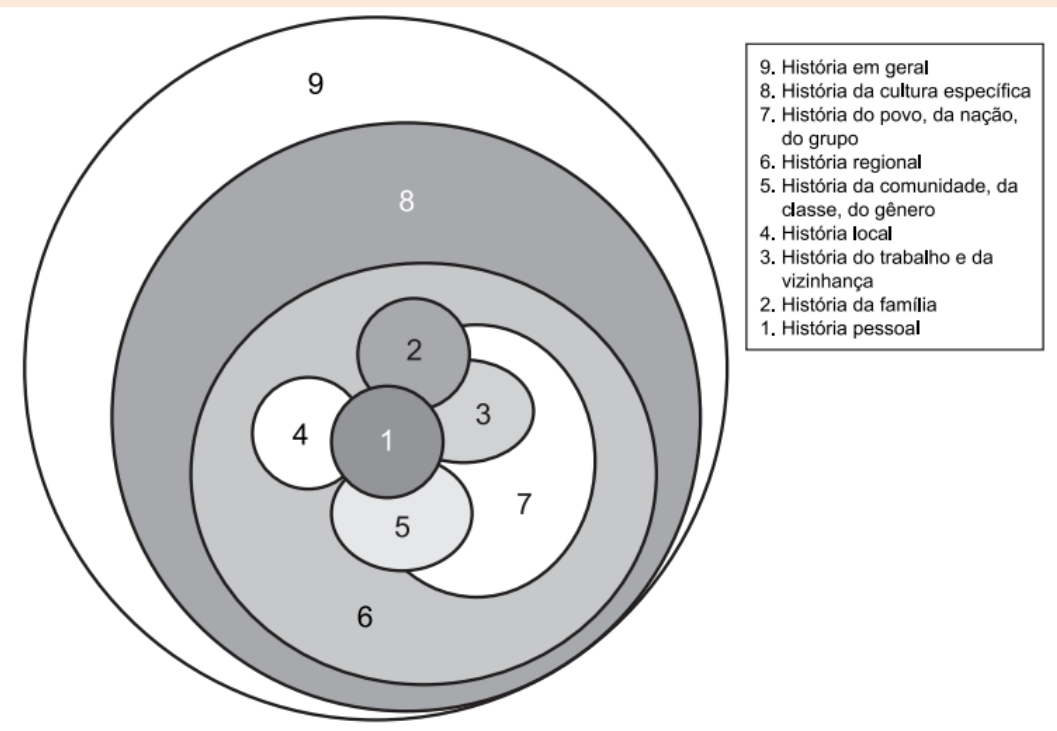

Para cada um dos círculos, incluem-se elementos sistemáticos e assistemáticos de formalização dos fatores instrucionais e educacionais nos ambientes familiar, escolar e profissional e com suas especificidades sociais, culturais e institucionais programadas, planejadas, dirigidas ${ }^{73}$. Ou seja, exemplificando (ainda com o exemplo de América Latina), o conhecimento de uma dada história regional, e dele o desenvolvimento de um sentimento de coletividade e pertencimento, se dá em meio às relações sociais institucionais e não institucionais, onde os elementos desta história se apresentam de modo sistemático e não sistemático, em ambientes formais de educação e em outros ambientes não comprometidos diretamente com o conhecimento científico, e envoltos à especificidades e relações culturais e sociais. Ao mesmo tempo em que se constrói no intelecto a noção de uma história regional, outras noções e histórias também são construídas concomitantemente. Portanto, é na práxis da vida que o sujeito constrói abstrações temporais sobre si próprio, família, comunidade, classe, gênero, nação, região e mundo. Estas noções se edificam no individuo de modo relacional - Martins propõe a interseção e interação entre os círculos -, em meio às experiências da vida cotidiana, não pressupondo, necessariamente, estágios de evolução elou complexidade.

\footnotetext{
72 Idem.

73 Idem.
} 
Assim, podemos indicar que no interior da cultura o sujeito interage com noções de histórias díspares que se apresentam de modo fragmentadas em espaços sociais diversos (família, escola, vizinhança, movimentos sociais, trabalho, grande mídia, etc), havendo uma estreita relação entre as experiências vividas individualmente, as interpretações subjetivas que delas decorrem, os dados da cultura histórica dispostos na sociedade (marcados pelo local e tempo) e a proximidade do sujeito aos processos de formação (compensatório e complementar). Este entendimento nos enriquece o debate ao propor que no interior da cultura histórica há uma pluralidade de noções de histórias ("história geral", "histórias regionais", "histórias locais", etc.) que se mesclam de modo concomitante e se apresentam aos sujeitos no presente de maneiras difusas, na intersecção dos espaços de suas relações sociais. Deste modo, cabe a consciência histórica operar sobre este passado que se apresenta de modo a atribuir inteligibilidade ao presente e sentido as ações futuras.

\section{considerações finais}

Acreditamos ter criado um entendimento provisório de alguns dos conceitos da teoria rüseniana que atualmente balizam os processos de expansão e ressignificação da área da Didática da História no Brasil. De modo sintético, relacionamos ciência e vida prática, consciência histórica e consciência utópica, narrativa e identidade, e cultura histórica e consciência histórica.

Estes conceitos atualmente instrumentalizam um número significativo e crescente de pesquisas no país, que gradativamente estão ampliando os campos e microcampos da área da Dídática da História. Para além do comum estudo das metodologias e formas de ensino, estão avançando no estudo da cognição histórica (situada e não situada), das ideias históricas em sociedade (meios midiáticos, produtos da indústria cultural, tradições, ritos e memórias) e no estudo metateórico sobre a ciência da história na intenção de refletir sobre os produtos historiográficos e suas proximidades com as carências identificadas na sociedade. ${ }^{74}$

Com o presente texto, esperamos ter lançado um pouco de luz sobre este processo ao refletirmos especificamente sobre os conceitos que fundamentam esta teoria, auxiliando, assim, futuros pesquisadores na área do ensino da história e teoria da história

${ }^{74}$ BAROM, W. C. C. . Os micro campos da Didática da História: A teoria da história de Jörn Rüsen, pesquisas acadêmicas e o ensino da história. Revista de Teoria da História , v. 11, p. 15-67, 2014 